\title{
Chemical Composition and Antifungal Activity of Essential Oils from Different Tissues of Japanese Cedar (Cryptomeria japonica)
}

\author{
Sen-Sung Cheng, ${ }^{\dagger}$ Huang-Yuan Lin,${ }^{\ddagger}$ And Shang-Tzen Chang* ${ }^{*} \dagger$ \\ School of Forestry and Resource Conservation, National Taiwan University, Taipei 106, Taiwan, and \\ The Experimental Forest, National Taiwan University, Nantou 557, Taiwan
}

\begin{abstract}
In this study antifungal activities of essential oils from different tissues of Japanese cedar (Cryptomeria japonica D. Don) against four wood decay fungi and six tree pathogenic fungi were investigated. In addition, the yields of essential oils obtained by water distillation were compared and their constituents determined by GC-MS analyses. The yield of essential oils from four tissues of Japanese cedar is in the decreasing order of leaf $(27.38 \mathrm{~mL} / \mathrm{kg})>$ bark $(6.31 \mathrm{~mL} / \mathrm{kg})>$ heartwood $(3.80 \mathrm{~mL} / \mathrm{kg})>$ sapwood $(1.27 \mathrm{~mL} / \mathrm{kg})$. Results obtained from the antifungal tests demonstrate that the essential oil of Japanese cedar heartwood used against Laetiporus sulphureus and Trametes versicolor and sapwood essential oil used against $L$. sulphureus had strong antifungal activities at $500 \mu \mathrm{g} / \mathrm{mL}$, with $I_{50}$ values of 39 , 91 , and $94 \mu \mathrm{g} / \mathrm{mL}$, respectively. Besides, the essential oils of Japanese cedar heartwood used against Rhizoctonia solani, Collectotrichum gloeosporioides, Fusarium solani, and Ganoderma australe had strong antifungal activities at $500 \mu \mathrm{g} / \mathrm{mL}$, with $\mathrm{IC}_{50}$ values of $65,80,80$, and $110 \mu \mathrm{g} / \mathrm{mL}$, respectively. GC-MS analyses showed that the sesquiterpene hydrocarbon compounds dominate in the essential oil from Japanese cedar heartwood, amounting to a total percentage of $82.56 \%$, with the major compounds of $\delta$-cadinene $(18.60 \%)$, isoledene $(12.41 \%)$, and $\gamma$-muurolene $(11.82 \%)$. It is proposed that the excellent antifungal activities of Japanese cedar heartwood essential oils might correlate with the presence of these compounds.
\end{abstract}

KEYWORDS: Cryptomeria japonica; heartwood; essential oil; GC-FID; GC-MS; wood decay fungi; tree pathogenic fungi; antifungal activity

\section{INTRODUCTION}

The search for simple bioactive compounds derived from plants that can be used against fungi has been a research direction for ecologically safe products (1). For instance, essential oils are known to contain a natural mixture of monoterpenes, sesquiterpenes, diterpenes, and hydrocarbons, with a variety of functional groups, giving them antibacterial, antifungal, antimite, antitermite, and antimosquito activities (29).

The Japanese cedar, Cryptomeria japonica D. Don, is a widely distributed conifer called "sugi" in Japanese. C. japonica is well-known in Taiwan as one of the important plantation tree species because of its beautiful yellowish red to red heartwood (10). Among plantation trees, it has one of the highest values as a building material for Japanese-style houses and is also commonly used for ceiling board, wall paneling, and posts (11). Because of its industrial importance, the chemical components

* Author to whom correspondence should be addressed (telephone +886 2-23630231-3196; fax +886-2-23654520; e-mail peter@ntu.edu.tw).

School of Forestry and Resource Conservation, National Taiwan University.

$\doteqdot$ The Experimental Forest, National Taiwan University. including terpenoids have been investigated by many researchers $(12-23)$. These compounds show various bioactivities such as antifungal (24-26), termiticidal $(27,28)$, antimite $(25,29)$, antipathogenic $(30,31)$, and antifeeding against snail species (32) and against the pill-bug (33) and develop resistance against the Cryptomeria bark borer (34). Our own results, reported in previous studies, have demonstrated that leaf essential oil from Japanese cedar has excellent antitermite (35) and antimosquito (8) activities. However, to the best of our knowledge there is no literature concerning the differences in antifungal activities of essential oils from different tissues of Japanese cedar against wood decay fungi and tree pathogenic fungi. Therefore, we studied the chemical composition of essential oils from four different tissues of the Japanese cedar by using gas chromatography-mass spectroscopy (GC-MS), and their antifungal activities against four wood decay fungi and six tree pathogenic fungi were also investigated herewith.

\section{MATERIALS AND METHODS}

Plant Material. Fifty-three aged Japanese cedar $(C$. japonica $\mathrm{D}$. Don), in the Taxodiaceae class, were collected in July 2000 from the Experimental Forest of National Taiwan University located in Nantou County in central Taiwan. The species was identified, and the voucher 
specimens (CJHO01, CJSO01, CJBO01, and CJLO01) including heartwood, sapwood, bark, and leaf, were deposited at the Laboratory of Wood Chemistry (School of Forestry and Resource Conservation, National Taiwan University).

Distillation of Essential Oils. Heartwood, sapwood, bark, and leaf of Japanese cedar were prepared from a green cut tree. The samples (200 g each), in triplicate, were subjected to water distillation in a Clevenger-type apparatus for $6 \mathrm{~h}(9)$, followed by determination of oil contents. Essential oils were stored in airtight containers prior to analysis by gas chromatography (GC) and GC-MS.

GC-Flame Ionization Detection (FID) Analysis. The essential oils from these different tissue types of Japanese cedar were analyzed using a Finnigan Trace GC with an FID and RTx-5MS (30 m $\times 0.25 \mathrm{~mm}$; film thickness, $0.25 \mu \mathrm{m}$ ). For heartwood essential oil, the initial oven temperature was maintained at $120^{\circ} \mathrm{C}$ for $1 \mathrm{~min}$ and programmed to increase at $2{ }^{\circ} \mathrm{C} / \mathrm{min}$ to $140{ }^{\circ} \mathrm{C}$ (held for $2 \mathrm{~min}$ ), then to $145^{\circ} \mathrm{C}$ at a rate of $0.5^{\circ} \mathrm{C} / \mathrm{min}$, maintained constant at $145^{\circ} \mathrm{C}$ for $5 \mathrm{~min}$, and then increased to $200{ }^{\circ} \mathrm{C}$ at a rate of $10{ }^{\circ} \mathrm{C} / \mathrm{min}$ (held for $5 \mathrm{~min}$ ). For sapwood, bark, and leaf essential oils, the oven temperature was held at $80{ }^{\circ} \mathrm{C}$ for $1 \mathrm{~min}$, then programmed to increase from 80 to $200{ }^{\circ} \mathrm{C}$ at a rate of $2{ }^{\circ} \mathrm{C} / \mathrm{min}$, and held for $5 \mathrm{~min}$. Helium was employed as the carrier gas at a $1 \mathrm{~mL} / \mathrm{min}$ flow rate. The injector temperature was maintained at $220{ }^{\circ} \mathrm{C}$. The samples $(1 \mu \mathrm{L})$ were injected neat with a 1:10 split ratio.

GC-MS Analysis. The compositions of essential oils from these different tissue types of Japanese cedar were analyzed on a Finnigan Trace GC-Polaris Q mass instrument (Finnigan-Spectronex), equipped with a fused silica column ( $30 \mathrm{~m} \times 0.25 \mathrm{~mm}$ i.d.), and coated with an RTx-5MS ( df $=0.25 \mu \mathrm{m})$. Mass spectra were recorded over the $35-$ $650 \mathrm{amu}$ range at $1 \mathrm{scan} / \mathrm{s}$, with an ionization energy of $70 \mathrm{eV}$ and an ion source temperature of $200{ }^{\circ} \mathrm{C}$. Helium was the carrier gas at a flow rate of $1 \mathrm{~mL} / \mathrm{min}$. The injector temperature was maintained at $220^{\circ} \mathrm{C}$. The oven temperatures were programmed as in the GC-FID analysis. The samples $(1 \mu \mathrm{L})$ were injected neat with a 1:10 split ratio. Quantification was performed using percentage peak area calculations using the GC-FID, and the identification of individual components was done using their relative retention indices and the Wiley/NBS Registry of Mass Spectral Database and NIST MS Search between the mass spectrum and a few authentic reference compounds. The quantity of compounds was obtained by integrating the peak area of the spectrograms.

Fungal Strains. The wood decay fungi and tree pathogenic fungi were obtained from the Culture Collection and Research Center of the Food Industry Research and Development Institute. The fungal strains used in experiments were as follows: four wood decay fungi [Lenzites betulina (CCRC 35296), Trametes versicolor (CCRC 35253), Laetiporus sulphureus (CCRC 35305), and Gloeophyllum trabeum (CCRC 31614)] and six tree pathogenic [Fusarium oxysporum (CCRC32121), Rhizoctonia solani (CCRC31626), Ganoderma australe (CCRC36246), Fusarium solani (CCRC32458), Pestalotiopsis funereal (CCRC35266), and Collectotrichum gloeosporioides (CCRC35003)]. Cultures of each of the fungi were maintained on potato dextrose agar (PDA) medium and were stored at $4{ }^{\circ} \mathrm{C}$.

Antifungal Assays. Antifungal assays were performed on the basis of the methods used in our previous studies $(2,36)$ with slight modifications. Briefly, 500, 200, 100, and $50 \mu \mathrm{g} / \mathrm{mL}$ of essential oils were added to sterilized PDA in $9 \mathrm{~cm}$ plates (Petri dish). After transfer of the mycelium of 10 fungi strains, the testing Petri dishes were incubated in the dark at $26 \pm 2{ }^{\circ} \mathrm{C}$ and $70 \%$ relative humidity. When the mycelium of fungi had reached the edges of the control Petri dishes (those without essential oils), the antifungal indices were calculated. Each test was repeated three times, and the data were averaged. The formula of antifungal indices is shown as

$$
\text { antifungal index }(\%)=\left(1-D_{\mathrm{a}} / D_{\mathrm{b}}\right) \times 100
$$

where $D_{\mathrm{a}}$ is the diameter of the growth zone in the experimental dish $(\mathrm{cm})$ and $D_{\mathrm{b}}$ is the diameter of the growth zone in the control dish (cm).

Statistical Analyses. To determine whether there was a statistically significant difference among different tissues of Japanese cedar essential oils against the fungi, Scheffe's method of SAS was used to analyze the difference of the antifungal index. Results with $P<0.05$ were considered to be statistically significant.

\section{RESULTS AND DISCUSSION}

Yields and Chemical Compositions of Essential Oils from Different Tissues. The yields of essential oils from different tissues of Japanese cedar ranged from 1.27 to $27.38 \mathrm{~mL} / \mathrm{kg}$ (Table 1). The yields of heartwood, sapwood, bark, and leaf essential oils of Japanese cedar were 3.80, 1.27, 6.31, and 27.38 $\mathrm{mL} / \mathrm{kg}$, respectively.

GC-MS analyses of the oils identified most of the compounds, which are listed in Table $\mathbf{1}$ along with their quantitative data. A total of 73 compounds were identified in the different tissues of Japanese cedar essential oils, constituting 91.94-100.00\% of the oils. These compounds could be assigned to seven different classes: monoterpene hydrocarbons, oxygenated monoterpenes, sesquiterpene hydrocarbons, oxygenated sesquiterpenes, diterpene hydrocarbons, oxygenated diterpenes, and other. In the Japanese cedar heartwood essential oil, 26 compounds, representing $97.44 \%$ of the oil, were identified in total (Table 1). This oil was characterized by a high content of the sesquiterpene hydrocarbons $(82.56 \%) ; \delta$-cadinene $(18.60 \%)$, isoledene (12.41\%), $\gamma$-muurolene (11.82\%), humulene $(9.43 \%)$, (-)-cubenene $(9.27 \%)$, and 1,1,3a-trimethyl-7-methylenedecahydrocyclopropa $[a]$ naphthalene $(6.79 \%)$ were the main constituents. Oxygenated sesquiterpenes were represented by three components, accounting for $13.44 \%$ of the oil. The most abundant constituents of the fraction were $\beta$-eudesmol (5.69\%) and $\delta$-cadinol $(5.24 \%)$. Diterpene hydrocarbons represented $1.03 \%$ of the oil, and the content of oxygenated diterpenes was even lower $(0.41 \%)$. These results are in agreement with those of Nagahama et al. $(16,17)$, who also found that the main constituent of wood essential oil was $\delta$-cadinene.

Twenty-one components of the sapwood essential oil from Japanese cedar were identified, representing for $96.69 \%$ of the oil. Sesquiterpene hydrocarbons predominated in the oil (36.80\%), with valencene (9.91\%), 1,1,3a-trimethyl-7-methylenedecahydrocyclopropa $[a]$ naphthalene $(7.61 \%), \delta$-cadinene $(6.11 \%)$, 2-methylene-5-(1-methylvinyl)-8-methylbicyclo[5.3.0]decane $(5.57 \%)$, and isoledene $(4.98 \%)$ as the main constituents. Four oxygenated sesquiterpenes constituted $12.81 \%$ of the oil, with $\beta$-eudesmol $(9.34 \%)$ and $\delta$-cadinol $(2.35 \%)$ as the two main constituents of the fraction. This oil was characterized by a high content of the diterpene hydrocarbons $(41.90 \%)$, and the main constituents were sclarene (27.56\%) and cupressene (12.55\%). Oxygenated diterpenes (two) and other (one) account for 4.94 and $0.24 \%$ of the oil, respectively.

In the bark essential oil of Japanese cedar, 38 compounds, representing $91.94 \%$ of the oil, were identified in total. The major fractions of the oil were monoterpene hydrocarbons and sesquiterpene hydrocarbons (37.63 and $33.31 \%$, respectively). 3-Carene $(18.62 \%)$ and limonene $(9.74 \%)$ were the two main constituents of the monoterpene hydrocarbon fraction; the main constituents of the sesquiterpene hydrocarbon fraction were cadala-1,3,5-triene $(10.51 \%)$, valencene $(3.85 \%)$, and $\gamma$-muurolene $(3.21 \%)$. Six oxygenated monoterpenes represent $7.53 \%$ of the oil; $\alpha$-terpineol (3.71\%) was the main constituent of the fraction. Oxygenated sesquiterpenes (two), diterpene hydrocarbons (four), oxygenated diterpenes (two), and other (one) constituted 3.02, $6.98,3.04$, and $0.43 \%$ of the oil, respectively. Yatagai et al. (34) found the major constituents of the essential oils of Japanese cedar inner barks were $\alpha$-pinene $(16.18-52.14 \%), 3$-carene $(6.57-13.16 \%)$, and limonene $(7.42-13.35 \%)$. 
Table 1. Constituents and Contents of Essential Oils from Different Tissues of Japanese Cedar

\begin{tabular}{|c|c|c|c|c|c|c|c|c|c|c|c|c|c|}
\hline \multirow[b]{2}{*}{ no. } & \multirow[b]{2}{*}{ compound $^{b}$} & \multirow[b]{2}{*}{$\left.\mathrm{R}\right|^{a}$} & \multicolumn{4}{|c|}{ relative $\%$} & \multirow[b]{2}{*}{ no. } & \multirow[b]{2}{*}{ compound $^{b}$} & \multirow[b]{2}{*}{$\mathrm{RI}^{\mathrm{a}}$} & \multicolumn{4}{|c|}{ relative $\%$} \\
\hline & & & bark & leaf & sapwood & heartwood & & & & bark & leaf & sapwood & heartwood \\
\hline 1 & m-cymene & 1025 & 1.25 & $-^{d}$ & - & - & 44 & (-)-cubenene & 2054 & - & - & - & 9.27 \\
\hline 2 & $\alpha$-pinene ${ }^{c}$ & 1031 & - & 3.08 & _- & _- & 45 & $\beta$-maaiene & 2061 & _- & - & - & 2.67 \\
\hline 3 & sabinene & 1056 & 3.30 & - & - & - & 46 & 1,1,3a-trimethyl-7-methylene- & 2063 & - & 0.33 & 7.61 & 6.79 \\
\hline 4 & $\beta$-pinene ${ }^{c}$ & 1058 & - & 0.70 & _- & - & & decahydrocyclopropa[a]- & & & & & \\
\hline 5 & 3 -carene ${ }^{c}$ & 1110 & 18.62 & 0.57 & - & - & & naphthalene & & & & & \\
\hline 6 & $p$-cymene ${ }^{c}$ & 1144 & - & 3.68 & - & - & 47 & $\alpha$-guriunene & 2066 & - & 7.91 & - & - \\
\hline 7 & limonene $^{c}$ & 1151 & 9.74 & - & - & - & 48 & isoledene & 2069 & - & 1.44 & 4.98 & 12.41 \\
\hline 8 & $\alpha$-terpinene ${ }^{c}$ & 1220 & - & 0.35 & - & - & 49 & valencene & 2074 & 3.85 & 19.91 & 9.91 & - \\
\hline 9 & artemiseole & 1252 & 0.66 & - & - & - & 50 & $\alpha$-cadinolc & 2085 & 1.38 & - & 2.35 & 5.24 \\
\hline 10 & $\beta$-methylallylbenzene & 1271 & 0.48 & - & - & - & 51 & unidentified & 2087 & - & - & - & 1.55 \\
\hline 11 & dehydro-p-cymene & 1288 & 0.88 & _- & - & - & 52 & $\beta$-eudesmol & 2091 & 1.64 & 5.90 & 9.34 & 5.69 \\
\hline 12 & terpinene-4-o|c & 1478 & - & 2.27 & - & - & 53 & eudesma-3,7(11)-diene & 2092 & 2.33 & 8.40 & - & - \\
\hline 13 & $\alpha$-terpineolc ${ }^{c}$ & 1503 & 3.71 & - & - & - & 54 & 4,5,9,10-dehydroisolongifolene & 2098 & 0.72 & - & - & _- \\
\hline 14 & $(-)$-bornyl acetate ${ }^{c}$ & 1674 & 1.41 & 0.97 & - & - & 55 & cadalene & 2109 & 0.83 & - & - & - \\
\hline 15 & nopol & 1694 & 0.54 & - & - & _- & 56 & azulene & 2110 & - & - & 0.65 & 0.41 \\
\hline 16 & eucarvone & 1721 & 0.44 & - & - & - & 57 & spathulenol & 2136 & - & - & 0.49 & - \\
\hline 17 & bornylene & 1751 & 0.93 & _- & - & - & 58 & longiverbenone & 2148 & - & - & 0.63 & 2.25 \\
\hline 18 & $\alpha$-terpinolene & 1771 & 2.43 & - & - & - & 59 & 4,4-dimethyl-3-3-methylbut-3- & 2188 & 0.99 & - & - & - \\
\hline 19 & $\alpha$-cubebene & 1807 & 0.83 & - & - & 0.76 & & enylidene)-2-methylene- & & & & & \\
\hline 20 & $\alpha$-copaene & 1828 & - & - & - & 0.22 & & bicyclo[4.1.0]heptane & & & & & \\
\hline 21 & germacrene-D & 1837 & - & _- & - & 0.62 & 60 & deoxyoblongifolion & 2234 & - & 0.39 & - & - \\
\hline 22 & $\beta$-caryophyllene ${ }^{c}$ & 1849 & - & - & - & 0.36 & 61 & 18-nor-isopimar-4(19),7,15-triene & 2250 & 2.02 & - & 0.92 & - \\
\hline 23 & $\alpha$-caryophyllene & 1856 & - & _- & - & 0.43 & 62 & verticiol & 2273 & - & - & 3.51 & 0.58 \\
\hline 24 & ylangene & 1863 & 0.67 & _- & - & - & 63 & cupressene & 2276 & 2.32 & - & - & - \\
\hline 25 & $\beta$-cubebene & 1875 & 2.55 & _- & - & 0.78 & 64 & pimarinal & 2286 & - & 0.47 & 1.43 & - \\
\hline 26 & $\gamma$-muurolene & 1931 & 3.21 & 0.29 & - & 11.82 & 65 & sandaracopimaradiene & 2289 & 0.91 & - & - & - \\
\hline 27 & $\alpha$-guaiene & 1940 & 0.60 & - & - & - & 66 & ferruginol $^{c}$ & 2302 & - & - & - & 0.45 \\
\hline 28 & (+)-cyclosativene & 1950 & 1.39 & _- & - & - & 67 & ent-kaur-16-ene ${ }^{c}$ & 2310 & - & 40.62 & 0.24 & - \\
\hline 29 & $\alpha$-muurolene & 1957 & 2.21 & - & 0.51 & 3.98 & 68 & abieta-8,11,13-triene & 2319 & 1.73 & - & 0.63 & - \\
\hline 30 & aromadendrene & 1961 & - & _- & - & 0.28 & 69 & sclareol & 2346 & - & 1.41 & - & _- \\
\hline 31 & $\gamma$-cadinene & 1970 & 1.70 & - & - & - & 70 & kauran-16-ol & 2374 & 2.61 & - & - & - \\
\hline 32 & 2,5-di-tert-butylphenol & 1972 & - & - & 0.24 & - & 71 & cupressene & 2376 & - & - & 12.55 & - \\
\hline 33 & cadina-1,3,5-triene & 1978 & 10.51 & - & - & - & 72 & totarol & 2381 & 0.43 & 0.33 & - & - \\
\hline 34 & $\alpha$-cadinene & 1980 & - & - & 6.11 & 18.6 & 73 & sclarene & 2399 & - & - & 27.56 & - \\
\hline 35 & cadina-3,9-diene & 1982 & - & 0.98 & - & - & & & & & & & \\
\hline 36 & cadala-1(10),3,8-triene & 1998 & 0.92 & - & 0.85 & 0.41 & iden & tified components (\%) & & 91.94 & 100.00 & 96.69 & 97.44 \\
\hline 37 & humulene & 2002 & - & _- & - & 9.43 & mon & loterpene hydrocarbons (\%) & & 37.63 & 8.38 & 0.00 & 0.00 \\
\hline 38 & 2-methylene-5-(1-methylvinyl)-8- & 2005 & - & - & 5.57 & - & oxyg & yenated monoterpenes $(\%)$ & & 7.53 & 3.24 & 0.00 & 0.00 \\
\hline & methylbicyclo[5.3.0]decane & & & & & & & quiterpene hydrocarbons (\%) & & 33.31 & 39.26 & 36.80 & 82.56 \\
\hline 39 & isopulegol acetate & 2019 & 0.77 & - & - & - & oxyg & yenated sesquiterpenes (\%) & & 3.02 & 5.90 & 12.81 & 13.44 \\
\hline 40 & $\gamma$-elemene & 2038 & - & _- & 0.61 & 1.41 & diter & pene hydrocarbons (\%) & & 6.98 & 40.62 & 41.90 & 0.00 \\
\hline 41 & 6-(2-butenyl)-1,5,5-trimethyl- & 2044 & 0.43 & - & - & - & oxyg & yenated diterpenes (\%) & & 3.04 & 2.60 & 4.94 & 1.03 \\
\hline & & & & & & & & & & 0.43 & 0.00 & 0.24 & 0.41 \\
\hline 42 & epi-bicyclosesquiphellandrene & 2046 & - & - & - & 0.77 & oil y & ield (mL/kg, v/dry wt) & & 6.31 & 27.38 & 1.27 & 3.80 \\
\hline 43 & caryophyllene oxide ${ }^{c}$ & 2051 & - & - & - & 0.26 & & & & & & & \\
\hline
\end{tabular}

${ }^{a}$ Retention index relative to $n$-alkanes on RTX-5MS column. ${ }^{b}$ By comparison of the mass spectrum with those of the computer mass libraries. ${ }^{c}$ By comparison with pure standard retention time. ${ }^{d}$ Not detected.

Japanese cedar leaf essential oil shows the presence of 20 identified components, accounting for $100.00 \%$ of the whole oil. Both sesquiterpene hydrocarbons (39.26\%) and diterpene hydrocarbons $(40.62 \%)$ were the main fractions of the whole, with valencene (19.91\%), eudesma-3,7(11)-diene (8.40\%), and $\alpha$-gurjunene $(7.91 \%)$ as the main sesquiterpene hydrocarbons, with ent-kaur-16-ene $(40.62 \%)$ as the main diterpene hydrocarbons. Five monoterpenes represent $8.38 \%$ of the oil; $p$ cymene $(3.68 \%)$ and $\alpha$-pinene $(3.08 \%)$ were the two main constituents of the fraction. Two oxygenated monoterpenes, one oxygenated sesquiterpene, and four oxygenated diterpenes constitute $3.24,5.90$, and $2.60 \%$ of the oil, respectively. Lee and Lin (14) also reported that the main constituents of leaf essential oil from Japanese cedar were (-)-kaurene (27.71\%), elemol (26.90\%), and sabinene (25.07\%).

Antifungal Activity of Essential Oils from Different Tissues against Wood Decay Fungi. To evaluate the antifungal activities of essential oils from different tissues of Japanese cedar against wood decay fungi, we first selected four typical fungi, two white-rot fungi, L. betulina and T. versicolor, and two

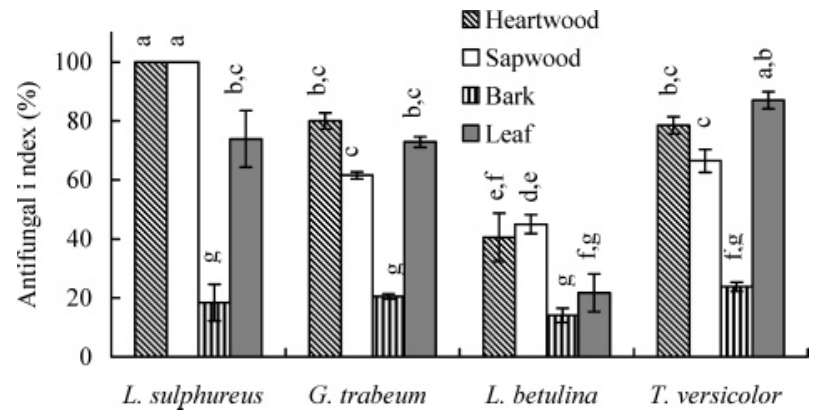

Figure 1. Antifungal activities of essential oils $(500 \mu \mathrm{g} / \mathrm{mL})$ extracted from four different tissues of Japanese cedar against four wood decay fungi. Each experiment was performed three times, and the data were averaged $(n=3)$. Numbers followed by different letters $(\mathrm{a}-\mathrm{g})$ are significantly different at the level of $P<0.05$ according to the Scheffe test.

brown-rot fungi, L. sulphureus and G. trabeum, as test strains. Figure 1 shows the antifungal activities of essential oils from different Japanese cedar tissues against wood decay fungi at a 
Table 2. $\quad \mathrm{IC}_{50}$ Values of Essential Oils from Different Tissues of Japanese Cedar against Four Wood Decay Fungi

\begin{tabular}{lrcrr}
\hline & \multicolumn{4}{c}{$\mathrm{I} \mathrm{C}_{50}(\mu \mathrm{g} / \mathrm{mL})$} \\
\cline { 2 - 5 } \multicolumn{1}{c}{ fungus } & heartwood & sapwood & bark & leaf \\
\hline T. versicolor & 91 & 139 & $>500$ & 118 \\
L. betulina & $>500$ & $>500$ & $>500$ & $>500$ \\
L. sulphureus & 39 & 94 & $>500$ & 260 \\
G. trabeum & 157 & 253 & $>500$ & 145 \\
\hline
\end{tabular}

concentration of $500 \mu \mathrm{g} / \mathrm{mL}$. On the basis of the results of the antifungal test, the antifungal indices of Japanese cedar heartwood essential oil were 40.5, 78.5, 100.0, and 80.0\% against L. betulina, T. versicolor, L. sulphureus, and G. trabeum, respectively, and the $\mathrm{IC}_{50}$ values were $>500,91,39$, and 157 $\mu \mathrm{g} / \mathrm{mL}$, respectively (Table 2). In addition, the antifungal indices of sapwood essential oils against the four wood decay fungi were $45.0,66.5,100.0$, and $61.6 \%$, respectively, and the $\mathrm{IC}_{50}$ values were $>500,139,94$, and $253 \mu \mathrm{g} / \mathrm{mL}$, respectively. The antifungal indices (the $\mathrm{IC}_{50}$ values) of leaf essential oils against four wood decay fungi were $21.7 \%$ ( $>500 \mu \mathrm{g} / \mathrm{mL}), 87.0 \%(118$ $\mu \mathrm{g} / \mathrm{mL}), 73.9 \%(260 \mu \mathrm{g} / \mathrm{mL})$, and $72.9 \%(145 \mu \mathrm{g} / \mathrm{mL})$, respectively. However, the antifungal indices of Japanese cedar bark essential oil against the four wood decay fungi did not exceed $24.0 \%$, and the $\mathrm{IC}_{50}$ values were $>500 \mu \mathrm{g} / \mathrm{mL}$, indicating that none of the bark essential oil could inhibit the fungal growth of L. betulina, T. versicolor, L. sulphureus, and G. trabeum.

On the basis of the above results, it is found that heartwood, sapwood, and leaf essential oils of Japanese cedar showed high activity against $T$. versicolor, $L$. sulphureus, and G. trabeum; the antifungal indices of these essential oils exceed $61.6 \%$. Among these, heartwood and sapwood essential oils completely inhibited the growth of brown-rot fungus ( $L$. sulphureus) at a concentration of $500 \mu \mathrm{g} / \mathrm{mL}$. The $\mathrm{IC}_{50}$ values of three essential oils in terms of antifungal activity against $T$. versicolor and $G$. trabeum are ranked as heartwood $(91$ and $157 \mu \mathrm{g} / \mathrm{mL})>$ leaf (118 and $145 \mu \mathrm{g} / \mathrm{mL}$ ) $>$ sapwood (139 and $253 \mu \mathrm{g} / \mathrm{mL}$ ) (Table 2). On the other hand, the order of $\mathrm{IC}_{50}$ values against $L$. sulphureus is heartwood $(39 \mu \mathrm{g} / \mathrm{mL})>\operatorname{sapwood}(94 \mu \mathrm{g} / \mathrm{mL})$ $>$ leaf $(260 \mu \mathrm{g} / \mathrm{mL})$. It is clear that, in comparison with $\mathrm{IC}_{50}$ values, heartwood essential oil has the strongest antifungal activities. Tellez et al. (37) studied the composition and biological activities of essential oil from Callicarpa americana and demonstrated that humulene $(10.0 \%)$ was a major compound of the steam-distilled oil, which could inhibit the fungal growth. Other constituents, that is, $\alpha$-copaene, germacrene- $\mathrm{D}, \beta$-caryophyllene, caryophyllene oxide, and ferruginol, were also shown to have good antifungal activity elsewhere $(36,38-40)$. Therefore, it could be suggested that the antifungal activity of heartwood essential oil against wood decay fungi is caused by these volatile compounds.

Antifungal Activity of Essential Oils from Different Tissues against Tree Pathogenic Fungi. The antifungal activities of essential oils from different Japanese cedar tissues against six tree pathogenic fungi at a concentration of $500 \mu \mathrm{g} / \mathrm{mL}$ are shown in Figure 2. For the activity studied, two seedling pathogens ( $F$. oxysporum and $R$. solani), two root pathogens ( $G$. australe and $F$. solani), and two leaf pathogens ( $P$. funereal and $C$. gloeosporioides) were used. As shown in Figure 2, the antifungal indices of the essential oils from four different tissues of Japanese cedar against $F$. oxysporum and $P$. funereal did not exceed 45.7 and $34.0 \%$ at a concentration of $500 \mu \mathrm{g} / \mathrm{mL}$, respectively, indicating that the essential oils from these four different tissues have no significant antifungal effects against

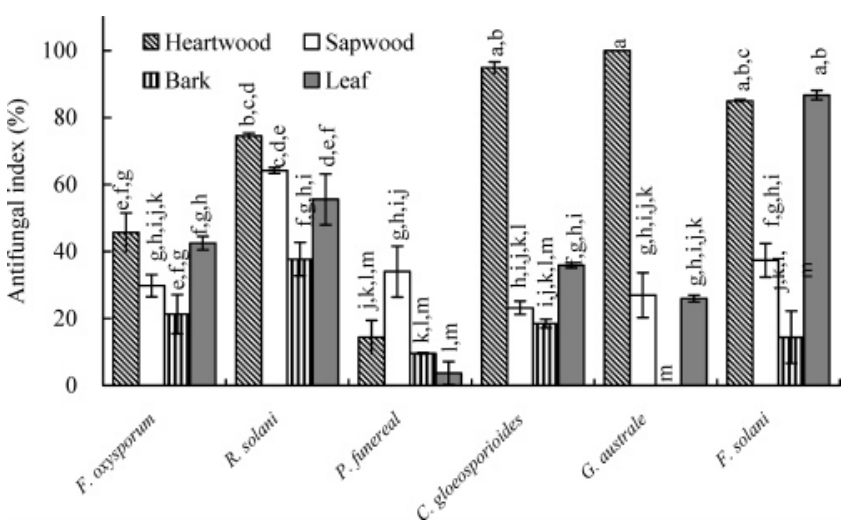

Figure 2. Antifungal activities of essential oils $(500 \mu \mathrm{g} / \mathrm{mL})$ extracted from four different tissues of Japanese cedar against six tree pathogenic fungi. Each experiment was performed three times, and the data were averaged $(n=3)$. Numbers followed by different letters $(a-m)$ are significantly different at the level of $P<0.05$ according to the Scheffe test.

Table 3. $\quad \mathrm{IC}_{50}$ Values of Essential Oils from Different Tissues of Japanese Cedar against Six Tree Pathogenic Fungi

\begin{tabular}{lcccr}
\hline & \multicolumn{4}{c}{$\mathrm{IC}_{50}(\mu \mathrm{g} / \mathrm{mL})$} \\
\cline { 2 - 5 } \multicolumn{1}{c}{ fungus } & heartwood & sapwood & bark & leaf \\
\hline F. oxysporum & $>500$ & $>500$ & $>500$ & $>500$ \\
R. solani & 65 & 240 & $>500$ & 430 \\
P. funereal & $>500$ & $>500$ & $>500$ & $>500$ \\
C. gloeosporioides & 80 & $>500$ & $>500$ & $>500$ \\
G. australe & 110 & $>500$ & $>500$ & $>500$ \\
F. solani & 80 & $>500$ & $>500$ & 235 \\
\hline
\end{tabular}

seedling pathogenic fungus $F$. oxysporum and leaf pathogenic fungus $P$. funereal. On the other hand, heartwood essential oil of Japanese cedar against root pathogenic fungi $G$. australe and $F$. solani, seedling pathogenic fungus $R$. solani, and leaf pathogenic fungus $C$. gloeosporioides had strong antifungal activities at $500 \mu \mathrm{g} / \mathrm{mL}$, with antifungal indices of $100.0,85.0$, 74.5 , and $94.9 \%$, respectively. In addition, the leaf essential oil exhibited an inhibitory effect against the root pathogenic fungus $F$. solani with an antifungal index of $86.7 \%$, and sapwood essential oil had also an excellent inhibitory effect against the seedling pathogenic fungus $R$. solani, with an antifungal index of $64.2 \%$. However, the antifungal indices of Japanese cedar bark essential oil against another four tree pathogenic fungi did not exceed $38.0 \%$, indicating that none of the bark essential oils could inhibit the fungal growth of G. australe, F. solani, $R$. solani, and C. gloeosporioides.

From a comparison of the $\mathrm{IC}_{50}$ values of heartwood, sapwood, and leaf essential oils against $G$. australe, $F$. solani, $R$. solani, and $C$. gloeosporioides, heartwood essential oil exhibited the highest antifungal index for four tree pathogenic fungi, followed by leaf and sapwood essential oils (Table 3). The $\mathrm{IC}_{50}$ values of heartwood essential oil against $G$. australe, $F$. solani, $R$. solani, and C. gloeosporioides were 110, 80, 65, and $80 \mu \mathrm{g} /$ $\mathrm{mL}$, respectively. In addition, the $\mathrm{IC}_{50}$ values of leaf essential oil were 235 and $430 \mu \mathrm{g} / \mathrm{mL}$ against $F$. solani and $R$. solani, and the $\mathrm{IC}_{50}$ value of sapwood essential oil was $240 \mu \mathrm{g} / \mathrm{mL}$ for $R$. solani. Kofujita et al. (31) have studied antifungal activities of the bark of $C$. japonica and demonstrated that ferruginol was the major compound of hexane extracts, which had a good antifungal activity against Alternaria alternate, Payricularia oryzae, $R$. solani, and $F$. oxysporum. Furthermore, $\beta$-caryophyllene oxide and $\alpha$-terpineol from Hypericum species essential oils were inhibitory to the growth of 10 agricultural pathogenic fungi (5 Fusarium species and 5 anastomosis groups of $R$. 
solani) at a concentration of $1 \mathrm{mg} / \mathrm{mL}$ (41). These results suggest that the antifungal activity of heartwood essential oil against tree pathogenic fungi is caused by these volatile compounds.

In conclusion, we investigated the antifungal activities of essential oils from different tissues of Japanese cedar against four wood decay fungi and six tree pathogenic fungi, which had not been previously reported. In addition, the yields of essential oils obtained by water distillation were compared and their constituents were determined by GC-MS analyses. The yield of essential oils from four tissues of Japanese cedar was in the decreasing order of leaf $(27.38 \mathrm{~mL} / \mathrm{kg})>$ bark $(6.31 \mathrm{~mL} /$ $\mathrm{kg})>$ heartwood $(3.80 \mathrm{~mL} / \mathrm{kg})>\operatorname{sapwood}(1.27 \mathrm{~mL} / \mathrm{kg})$. Antifungal tests demonstrated that the essential oils of Japanese cedar heartwood used against $L$. sulphureus and $T$. versicolor and sapwood essential oil used against $L$. sulphureus had strong antifungal activities at $500 \mu \mathrm{g} / \mathrm{mL}$, whereas the $\mathrm{IC}_{50}$ values were 39, 91 , and $94 \mu \mathrm{g} / \mathrm{mL}$, respectively. Moreover, the essential oils of Japanese cedar heartwood had strong antifungal activities against $R$. solani, $C$. gloeosporioides, $F$. solani, and $G$. australe at $500 \mu \mathrm{g} / \mathrm{mL}$; the $\mathrm{IC}_{50}$ values were $65,80,80$, and $110 \mu \mathrm{g} /$ $\mathrm{mL}$, respectively. Using GC-MS analyses, the sesquiterpene hydrocarbon compounds dominate in the essential oil from Japanese cedar heartwood, amounting to a total percentage of $82.56 \%$, with the major compounds being $\delta$-cadinene $(18.60 \%)$, isoledene $(12.41 \%)$, and $\gamma$-muurolene $(11.82 \%)$. It is proposed that the excellent antifungal activities of Japanese cedar heartwood essential oils might correlate with the presence of these compounds. Thus, the mechanisms of these compounds against fungal growth are worthy of further investigation.

\section{ACKNOWLEDGMENT}

We thank H.-Y. Lin (Experimental Forest of National Taiwan University) for supplying $C$. japonica materials and Dr. ShengYang Wang and Pi-Wen Tsai of the Institute of BioAgricultural Sciences, Academia Sinica, Taiwan, for assistance in the GCMS analysis.

\section{LITERATURE CITED}

(1) Sridhar, S. R.; Rajagopal, R. V.; Rajavel, R.; Masilamani, S.; Narasimhan, S. Antifungal activity of some essential oils. $J$. Agric. Food Chem. 2003, 51, 7596-7599.

(2) Chang, S. T.; Wang, S. Y.; Wu, C. L.; Chen, P. F.; Kuo, Y. H. Comparisons of the antifungal activities of cadinane skeletal sesquiterpenoids from Taiwania (Taiwania cryptomerioides Hayata) heartwood. Holzforschung 2000, 54, 241-245.

(3) Chang, S. T.; Chen, P. F.; Chang, S. C. Antibacterial activity of essential oils and extracts from Taiwania (Taiwania cryptomerioides Hayata). Q. J. Chin. For. 2000, 33, 119-125.

(4) Chang, S. T.; Chen, P. F.; Wang, S. Y.; Wu, H. H. Antimite activity of essential oils and their constituents from Taiwania cryptomerioides. J. Med. Entomol. 2001, 38, 455-457.

(5) Chang, S. T.; Chen, P. F.; Chang, S. C. Antibacterial activity of leaf essential oils and their constituents from Cinnamomum osmophloeum. J. Ethnopharmacol. 2001, 77, 123-127.

(6) Chang, S. T.; Cheng, S. S.; Wang, S. Y. Antitermitic activity of essential oils and components from Taiwania (Taiwania cryptomerioides). J. Chem. Ecol. 2001, 27, 717-724.

(7) Chang, S. T.; Cheng, S. S. Antitermitic activity of leaf essential oils and components from Cinnamomum osmophloeum. J. Agric. Food Chem. 2002, 50, 1389-1392.

(8) Cheng, S. S.; Chang, H. T.; Chang, S. T.; Tsai, K. H.; Chen, W. J. Bioactivity of selected plant essential oils against the yellow fever mosquito Aedes aegypti larvae. Bioresour. Technol. 2003, $89,99-102$.
(9) Cheng, S. S.; Liu, J. Y.; Tsai, K. H.; Chen, W. J.; Chang, S. T. Chemical composition and mosquito larvicidal activity of essential oils from leaves of different Cinnamomum osmophloeum provenances. J. Agric. Food Chem. 2004, 52, 4395-4400.

(10) Chang, S. T.; Cheng, S. S. Effects of environmental factors on the color of sugi (Cryptomeria japonica D. Don) yellowish heartwood. Holzforschung 2001, 55, 459-463.

(11) Hon, D. N. S.; Minemura, N. Color and discoloration. In Wood and Cellulosic Chemistry; Hon, D. N. S., Shiraish, N., Eds.; Dekker: New York, 1991; pp 395-454.

(12) Ito, S.; Kodama, M.; Nishiya, H.; Narita, S. Structure of cryptomerone, a bisabolane sesquiterpene from Cryptomeria japonica. Tetrahedron Lett. 1969, 37, 3185-3186.

(13) Shieh, B.; Iizuka, Y.; Matsubara, Y. Monoterpenoid and sesquiterpenoid constituents of the essential oil of sugi (Cryptomeria japonica D. Don.). Agric. Biol. Chem. 1981, 45, 1493-1495.

(14) Lee, C. L.; Lin, H. Y. Study on the essential oil of tree leaves 1. The leaf oil constituents of Cryptomeria japonica. Bull. Exp. For. Natl. Taiwan Univ. 1986, 169, 1-7.

(15) Nagahama, S.; Tazaki, M. Terpenoids of wood oil of sugi (Cryptomeria japonica). Peculiarities of obisugi variety. Mokuzai Gakkaishi 1993, 39, 1077-1083.

(16) Nagahama, S.; Tazaki, M.; Sanetika, T.; Nishimura, K.; Tajima, M. Terpenoids of the wood oil of sugi (Cryptomeria japonica) V. Components of form Ayasugi. Mokuzai Gakkaishi 1998, 44, $282-286$.

(17) Nagahama, S.; Iwaoka, T.; Ashitani, T. Terpenoids of the wood oil of sugi (Cryptomeria japonica) VI. Components of elite clones KenKuma-3, KenKoyu-3 and KenAira-14. Mokuzai Gakkaishi 2000, 46, 225-230.

(18) Nagahama, S.; Tukamoto, T.; Torii, N.; Sonoda, T.; Yamanobe, $\mathrm{T}$. Terpenoids of the wood oil of sugi (Cryptomeria japonica) VII. Components of elite clones minamatasho-4, and five others. Mokuzai Gakkaishi 2001, 47, 487-492.

(19) Nagahama, S.; Fujii, H.; Sonoda, T.; Sasaki, M. Terpenoids of the wood oil of sugi (Cryptomeria japonica) VIII. Components of kenkunisaki-5 and five others elite clones. Mokuzai Gakkaishi 2002, 48, 380-386.

(20) Su, W. C.; Fang, J. M.; Cheng, Y. S. Abietanes and kauranes from leaves of Cryptomeria japonica. Phytochemistry 1994, 35, $1279-1284$

(21) Su, W. C.; Fang, J. M.; Cheng, Y. S. Labdanes from leaves of Cryptomeria japonica. Phytochemistry 1994, 37, 1109-1114.

(22) Su, W. C.; Fang, J. M.; Cheng, Y. S. Sesquiterpenes from leaves of Cryptomeria japonica. Phytochemistry 1995, 39, 603-607.

(23) Su, W. C.; Fang, J. M.; Cheng, Y. S. Diterpenoids from leaves of Cryptomeria japonica. Phytochemistry 1996, 41, 255-261.

(24) Nakajima, K.; Yoshimoto, T.; Fukuzumi, T. Substance inhibiting growth of shiitaka mycelium in sugi wood (Cryptomeria japonica D. Don). Mokuzai Gakkaishi 1980, 26, 698-702.

(25) Morita, S.; Yatagai, M.; Ohira, T. Antimite and antifungi activities of the hexane extractives from yakusugi bogwood. Mokuzai Gakkaishi 1991, 37, 352-357.

(26) Morita, S.; Hidaka, T.; Yatagai, M. Antifungal compounds of the extractives of yakusugi (Crypromeria japonica D. Don). Wood Preserv. 1997, 23, 11-19.

(27) Yatagai, M.; Miyazaki, Y.; Ohira, T. Extractives from yakusugi bogwood and their termicidal activity and growth regulation effects on plant seeds. Mokuzai Gakkaishi 1991, 37, 352-357.

(28) Sogabe, A.; Kinjo, K.; Abe, F.; Yamauchi, T.; Yaga, S. Termiticidal substances from the heartwood of Cryptomeria japonica D. Don. Mokuzai Gakkaishi 2000, 46, 124-131.

(29) Morita, S.; Yatagai, M. Antimite components of the hexane extractives from domaiboku yakusugi (Cryptomeria japonica). Mokuzai Gakkaishi 1994, 40, 996-1002.

(30) Yamada, T.; Tamura, H.; Mineo, K. The response of sugi (Cryptomeria japonica D. Don) sapwood to fungal invasion following attack by the sugi bark borer. Physiol. Mol. Plant Pathol. 1988, 33, 429-442. 
(31) Kofujita, H.; Fujino, Y.; Sasaki, T.; Hasebe, M.; Ota, M.; Suzuki, $\mathrm{K}$. Antifungal activity of the bark of Cryptomeria japonica and its relevant components. Mokuzai Gakkaishi 2001, 47, 479486.

(32) Chen, X. H.; Kim, C. S.; Kashiwagi, T.; Tebayashi, S.; Horiike, M. Antifeedants against Acusta despesta from the Japanese cedar, Cryptomeria japonica II. Biosci., Biotechnol., Biochem. 2001, $65,1434-1437$.

(33) Morisawa, J.; Kim, C. S.; Kashiwagi, T.; Tebayashi, S.; Horiike, M. Repellents in the Japanese cedar, Cryptomeria japonica against the pill-bug, Armadillidium vulgare. Biosci., Biotechnol., Biochem. 2002, 66, 2424-2428.

(34) Yatagai, M.; Makihara, H.; Oba, K. Volatile components of Japanese cedar cultivars as repellents related to resistance to Cryptomeria bark borer. J. Wood Sci. 2002, 48, 51-55.

(35) Cheng, S. S.; Chang, S. T. Antitermitic activity of essential oils from Cryptomeria japonica. Q. J. Chin. For. 2002, 35, 193199.

(36) Chang, S. T.; Wang, S. Y.; Wu, C. L.; Su, Y. C.; Kuo, Y. H. Antifungal compounds in the ethyl acetate soluble fraction of the extractives of Taiwania (Taiwania cryptomerioides Hayata) heartwood. Holzforschung 1999, 53, 487-490.

(37) Tellez, M. R.; Dayan, F. E.; Schrader, K. K.; Wedge, D. E.; Duke, S. O. Composition and some biological activities of the essential oils of Callicarpa americana. J. Agric. Food Chem. 2000, 48, 3008-3012.
(38) Saito, K.; Okabe, T.; Inamori, Y.; Tsujibo, H.; Miyake, Y.; Hiraoka, Y.; Ishida, N. The biological properties of monoterpenes-Hypotensive effects on rats and antifungal activities on plant pathogenic fungi of monoterpenes. Mokuzai Gakkaiishi 1996, 42, 677-680.

(39) Costa, T. R.; Fernandes, O. F. L.; Santos, S. C.; Oliveira, C. M. A.; Liao, L. M.; Ferri, P. H.; Paula, J. R.; Ferreira, H. D.; Sales, B. H. N.; Silva, M. R. R. Antifungal activity of volatile constituents of Eugenia dysenterica leaf oil. J. Ethnopharmacol. 2000, 72, 111-117.

(40) Krauze-Baranowska, M.; Mardarowicz, M.; Wiwart, M.; Poblocka, L.; Dynowska, M. Antifungal property of the essential oils from some species of the genus Pinus. Z. Naturforsch. C 2002, 57, 478-482.

(41) Cakir, A.; Kordali, S.; Zengin, H.; Izumi, S.; Hirata, T. Composition and antifungal activity of essential oils isolated from Hypericum hyssopifolium and Hypericum heterophyllum. Flavour Fragrance J. 2004, 19, 62-68.

Received for review September 16, 2004. Revised manuscript received November 18, 2004. Accepted November 21, 2004. This study was supported by a grant from the Council of Agriculture (COA) of the Executive Yuan, Taiwan. We thank the COA for the financial support.

JF0484529 